\title{
BEHAVIORAL AND PHYSIOLOGICAL RESPONSES OF EARED GREBES (PODICEPS NIGRICOLLIS) TO VARIATIONS IN BRINE SHRIMP (ARTEMIA FRANCISCANA) DENSITIES
}

\author{
Joe N. Caudell1,2 and Michael R. Conover ${ }^{1}$
}

\begin{abstract}
Eared Grebes (Podiceps nigricollis) use the Great Salt Lake (GSL) primarily as a fall staging area. They feed on brine shrimp (Artemia franciscana) to build up energy reserves to complete their southward migration. Whereas it has been speculated that timing of grebe departure from the GSL is due to declining shrimp density, this hypothesis has not been tested. We monitored grebe weight, behavior, and departure dates to test this hypothesis and to determine the effects of declining shrimp densities on Eared Grebes during 1999, 2000, and 2001 when there were different shrimp densities. Despite differences in shrimp densities, grebes left the GSL about the same time each year. Juvenile and subadult mass was significantly lighter $(P<0.001)$ in 1999 than in 2000 or 2001 ; however, adult grebe mass was similar in 1999 and 2000, despite the large difference in available of food. While there was no difference $(P>0.05)$ in dive or surface duration between 1999 and 2000, there were differences in the percentage of time spent foraging. Our results indicated that at shrimp densities $<0.1$ shrimp $\cdot \mathrm{L}^{-1}$, grebes increased their foraging effort to offset the declining food resource instead of departing the GSL at an earlier date.
\end{abstract}

Key words: Eared Grebe, Podiceps nigricollis, mass, behavior, brine shrimp, Artemia franciscana, Great Salt Lake, brine shrimp densities, migration.

The Great Salt Lake (GSL) is classified as a Western Hemispheric Shorebird Reserve because of its value to migratory shorebirds. It is host to many avian species, including American White Pelicans (Pelecanus erythrorhynchos), American Avocets (Recurvirostra americana), White-faced Ibises (Plegadis chihi), Blacknecked Stilts (Himantopus mexicanus), California Gulls (Larus californicus), Wilson's Phalaropes (Phalaropus tricolor), and Eared Grebes (Podiceps nigricollis; Rawley 1980, Paul et al. 1999a, 1999b). These and other species use the lake for breeding or as a migration staging area.

Approximately 2.5 million Eared Grebes are found in North America (O'Donnel and Fjeldsa 1997). Thousands of grebes use the lake during the spring and summer and about half of the grebes in the United States use the GSL as a staging area for fall migration. Their diet on the GSL largely consists of brine shrimp (Artemia franciscana; Cullen et al. 1999). Indirectly competing with the birds for brine shrimp are commercial harvesters. Brine shrimp cysts are commercially valuable as food for prawn farms, and the shrimp cysts from the GSL are among the most valuable cysts in the world because of their high hatchability (M. Hunwick, Utah Division of Wildlife Resources [UDWR], personal communication). The quantity of the shrimp cyst harvest from the previous fall can potentially affect the amount of shrimp available to Eared Grebes and other birds during the following year.

The UDWR developed the GSL Ecosystem Project to manage the biological, commercial, and recreational interests of the lake using an ecosystem approach. The primary focus of the project is to maintain the health of the lake and provide resources for animals dependent upon the GSL while maintaining a harvestable surplus of brine shrimp cysts. The brine shrimp of the GSL overwinter as cysts that are in diapause. Diapause is broken in the spring. During the spring and summer, brine shrimp reproduce by giving birth to live shrimp. Once the brine shrimp population reaches a density where they graze down the algae in the GSL, they begin to produce diapausal cysts that do not hatch until the following spring or until their diapause is broken by some event (Stephens 1999). These are the shrimp cysts that are harvested. Hence, the brine shrimp

1Jack H. Berryman Institute, Utah State University, 5210 Old Main Hill, NR 206, Logan, UT.

2Present address: USDA / APHIS / Wildlife Services, Purdue University, SMTH Hall, West Lafayette, IN 47907. 
population in the GSL the following year is dependent upon the density of overwintering cysts that remain in the lake after fall harvesting.

Eared Grebes arrive on the GSL in late summer and early fall and begin foraging heavily on the declining brine shrimp population. Unlike most birds, grebes forage throughout most of the day, taking only short breaks to preen and rest (Jehl 1988). This foraging strategy is probably due to the large number of brine shrimp that they must catch daily. Any significant reduction in shrimp density, resulting from overharvesting or other environmental variables, could result in starvation. Therefore, knowing what density of brine shrimp must be available for grebes is of primary importance in managing Eared Grebes on the GSL.

Brine shrimp densities may also play an important role in the timing of grebe migration. Jehl (1988) reported a correlation between grebe departure dates and shrimp densities based on 3 years of observations from Mono Lake, California. He hypothesized that migration of Eared Grebes is triggered primarily by declining shrimp densities and that grebes will stop foraging and continue their fall migration after shrimp populations reach a minimum threshold. However, his hypothesis has not been tested on the GSL. It is unclear exactly how grebes respond to declining food resources. Therefore, we examined grebe foraging behavior (time budget), body weights, prey selection, and departure dates in relation to different shrimp densities on the GSL.

One approach that could be used to experimentally test how grebes respond to different shrimp densities is to compare the behavior and weight of captive grebes maintained on different densities of brine shrimp. Grebes maintained on decreasing shrimp density should cease feeding once the shrimp density decreases below the threshold point and should begin wing flapping in preparation for migration, if migration is indeed tied to shrimp densities. Alternatively, grebes provided with a continuously high density of shrimp should continue to forage and should not wing flap. We attempted this approach in fall 1999 and found that grebes were difficult to maintain in captivity because they would not feed (unpublished data).

Another approach is to experimentally manipulate brine shrimp populations in the GSL during the fall and monitor behavior, departure dates, and weights of Eared Grebes; however, manipulating the prey base of an ecosystem over multiple years is not practical. Therefore, we capitalized on natural, yearly variation in shrimp density (Stephens 1999, 2000) to test Jehl's (1988) hypothesis that grebes alter their fall migration dates based on shrimp densities. We also used these fluctuating densities to determine how grebes react behaviorally and physiologically to changes in shrimp densities. Specifically, we monitored their daily activity budget (Wakely 1978, Gates et al. 2001), weights, and prey selection over the course of 3 years.

\section{STUdy SITE}

The GSL is a hypersaline lake that covers $4290 \mathrm{~km}^{2}$ in north central Utah $\left(112^{\circ} 30^{\prime} 6^{\prime \prime} \mathrm{W}\right.$, $42^{\circ} \mathrm{N}$; 4200 feet above mean sea level; Gliwicz et al. 1995). The Union Pacific Railroad Causeway (UPRC) divides the GSL into 2 major areas, essentially creating 2 separate lakes with unique characteristics (Butts 1980). The North Arm of the GSL, located north of the UPRC, is characterized by high salinity levels, no substantial inlets of fresh water, and few brine shrimp or other invertebrates, and it is dominated by reddish brown algae and diatoms (Butts 1980). The South Arm is located south of the UPRC and receives most of the fresh water entering the lake and has a much lower level of brine (8\%-12\% during our study; C. Perschon, UDWR, personal communication). Blue-green algae dominate in the South Arm (Butts 1980). Most of the brine shrimp production occurs in the South Arm. Observations of grebes were limited to the South Arm because grebes are rarely found in the North Arm (D.S. Paul, UDWR, personal communication). The South Arm of the GSL is further divided by the Antelope Island Causeway (AIC) into 2 areas: Gilbert Bay (the area between the UPRC and AIC) and Farmington Bay (the area south of the AIC).

We captured and observed Eared Grebes on both sides of the AIC. Attempts were made to observe birds from a boat further out in the GSL; however, the presence of the boat caused the birds to alter their behavior. Therefore, we made our observations of Eared Grebes from a vehicle parked on the AIC. Cars are common along the AIC and are ignored by foraging grebes when occupants remain in their vehicles. 
We were able to make observations on calm days up to $500 \mathrm{~m}$ from the AIC with the use of Nikon $10 \times 50$ binoculars. We did not monitor behavior after dark because Eared Grebes do not forage at night (Cooper et al. 1984). Juvenile Eared Grebes were captured primarily around the bridge on the western end of the AIC and around the culvert on the eastern end of the AIC. Adults were captured further away from the causeway.

\section{Methods}

\section{Shrimp Density}

Brine shrimp were sampled in 1999, 2000, and 2001 by the UDWR and the U.S. Geological Survey at the same 17 randomly located sites on the GSL using a 0.5-m-diameter, 2-mlength, 183- $\mu$ m-mesh plankton net (Stephens 2000). Samples were made at least monthly from December through April, and biweekly to weekly from June through November. Shrimp were preserved in either formalin or alcohol and counted and classified in each agency's respective laboratory. Stephens (2000) provides additional information on the collection, enumeration, and classification of brine shrimp sampled on the GSL.

\section{Focal-animal Sampling}

We collected focal-animal samples (Altmann 1974) of grebes between 7 May and 11 November 1999 and between 11 May and 16 November 2000 to determine the length of time a grebe spends in each aspect of a diving bout. We defined a diving bout as the time spent underwater in a dive plus the length of time spent on the surface between dives. When observing birds in a diving bout, we recorded both the surface duration and the dive duration. Observations were made of solitary grebes or leucistic grebes (Jehl 1985) in groups of normally pigmented birds. Grebes were not separated by sex or age because those characters could not be determined from a distance (Jehl 1988, Jehl et al. 1998). Observation durations for individual birds ranged from 5 minutes to 60 minutes. This range is wide because grebes swimming away from the causeway can quickly reach a distance where they are not observable or can combine with larger groups where it is no longer possible to distinguish individual birds or small groups. We used the mean dive and surface durations for each Eared Grebe in our statistical analysis.

\section{Scan Sampling}

We used scan sampling (Altmann 1974) to observe larger numbers of birds throughout the day to determine the percentage of time grebes spent in a particular activity. We observed birds during 1999 between 7 May and 23 November, during 2000 between 8 May and 29 November, and during 2001 between 1 June and 28 November. Activities included the diving portion of a diving bout, the surface portion of a diving bout, surface swimming, preening, loafing, feeding on the surface, courtship behavior, and wing flapping. We defined the diving portion of a diving bout as the time during a diving bout when the grebes were underwater, presumably foraging. We defined the surface potion of a diving bout as the period between dives spent on the surface. During this behavior grebes swam but stayed in the same general area where they surfaced, and then dove again within the next few minutes. We defined surface swimming as swimming across the surface of the lake without diving. Energetically, these 2 behaviors are probably similar; however, the behavior defined as the surface portion of a diving bout implies the birds are engaged in foraging. Feeding on the surface involved grebes dabbling or eating flies from the surface of the water (Jehl 1988). Loafing involved the bird sitting on the surface with no apparent movement across the water. Other behaviors exhibited by the grebes are self-explanatory.

To begin the scan, a group of grebes $(\leq 12$ birds) was located on the lake. Observing more than 12 birds made it difficult to keep track of all individuals and record behaviors. We drove along the causeway until a group was spotted. We then watched those birds until they swam out of sight, merged with another group, or had been watched 1 hour (the maximum time spent observing any single group of birds). We then drove along the causeway until another suitable group was located. Instead of keeping track of behaviors of individuals in a group, we recorded the number of birds exhibiting each behavior at a specific instant of time. Observations were made at 3-minute intervals spaced throughout a day, from sunrise to sunset, at least 3 times per season in 1999. Scan samples were grouped into 3 seasons. The 
spring season was from the day the grebes arrived (mid-April) until the end of May; summer season was June, July, and August; and fall season was September, October, and November. In 2000 and 2001, scan samples were made using the same procedure, but the frequency was increased to at least 3 times per month instead of 3 times per season.

\section{Eared Grebe Mass}

We captured grebes on the GSL using drive-by netting (Caudell 2001) from 20 September to 18 November 1999, from 21 April through 17 June 2000, and from 16 June to 19 November 2001. For each grebe we determined sex (Jehl et al. 1998), age (Storer and Jehl 1985), and mass (using an electronic balance). During 2000 we also recorded the stage of molting. After collecting these data, we either kept the grebes for metabolic rate experiments (Caudell 2001) or released them immediately.

\section{Statistical Analysis}

We used an alpha of 0.05 for all tests of statistical significance. All statistical analyses were performed using Statistical Package for the Social Sciences (2000).

SHRIMP ABUNDANCE DATA.-We created a line graph using mean shrimp densities from all sampling stations for each of the sampling days during 1999, 2000, and 2001. We used the the general linear models (GLM) procedure to identify differences in shrimp densities between fall 1999, 2000, and 2001. We also calculated a post-hoc effect size for each analysis.

FoCAL SAMPLE DATA.-We used a 1-sample $t$ test (Stevens 1999) to determine if the mean dive duration we observed differed from those reported by Jehl (1988). We used the Pearson product-moment correlation statistic to determine if the surface duration was correlated with the preceding dive duration (Stevens 1999).

SCAN SAMPLE DATA.- - The statistical unit for our analysis was the entire flock of grebes observed during a scan using the percentage of time the individuals of the flock spent in an activity. We used the flock as the statistical unit because individuals within the flock were probably not independent (Hulbert 1984, Adair et al. 1996). For the 1999 and 2000 data, we used the Pearson product-moment correlation statistic to determine if behaviors were correlated to the size of the flock. We initially compared percentage of time spent in the diving and surface portions of the diving bout using the GLM procedure followed by an estimate of effect size $\left(\mathrm{Eta}^{2}\right)$ and a post-hoc analysis of power. Year, month, and hour were used as fixed factors to determine whether the time spent in different behaviors varied among these variables. We used the GLM procedure to determine if time spent foraging differed between 1999, 2000, and 2001. This test was followed by a post-hoc analysis using Tukey HSD to determine which years differed.

EARED GREBE MASS.-We used the GLM procedure to identify differences between fall 1999, 2000, and 2001 adult, subadult, and juvenile Eared Grebe weights.

\section{RESULTS}

Shrimp Density

Overall, shrimp densities in fall 2000 (mean $=2.7$ shrimp $\left.\cdot \mathrm{L}^{-1}, s=1.8\right)$ and fall 2001 $\left(\right.$ mean $=2.9$ shrimp $\left.\cdot \mathrm{L}^{-1}, s=1.0\right)$ were significantly higher $(P<0.005)$ than in fall 1999 (mean $=0.8 \mathrm{shrimp} \cdot \mathrm{L}^{-1}, s=1.3$, Fig. 1). Shrimp densities did not differ $(P=0.951)$ between fall 2000 and fall 2001.

\section{Focal-animal Sampling}

We recorded diving times of 57 Eared Grebes during 1999 and 8 grebes during 2000. Dive duration of individual birds ranged from 1.6 to 46.5 seconds. Time spent on the surface between dives of individual birds ranged from 6.2 to 80.7 seconds.

There were no significant differences $(P=$ 0.30) in diving duration between 1999 (mean $=23.1$ seconds, $s=6.6, n=57$ ) and 2000 $($ mean $=20.5$ seconds, $s=4.8, n=8)$. Dive duration did not differ throughout the year by month $\left(F=1.46, P=0.03, \mathrm{Eta}^{2}=0.13\right)$. Dive duration for both years combined (mean $=$ 22.8 seconds $)$ did not differ significantly $(P=$ $0.13)$ from those reported by Jehl (1988; mean $=24.0$ seconds). Time spent in the surface duration portion of a diving bout between $1999($ mean $=16.5$ seconds, $s=6.0, n=9)$ and 2000 (mean $=19.9$ seconds, $s=4.9, n=8$ ) did not differ significantly $(P=0.22)$. There was no correlation $(r=0.06)$ between the dive duration of Eared Grebes and the following surface interval. 


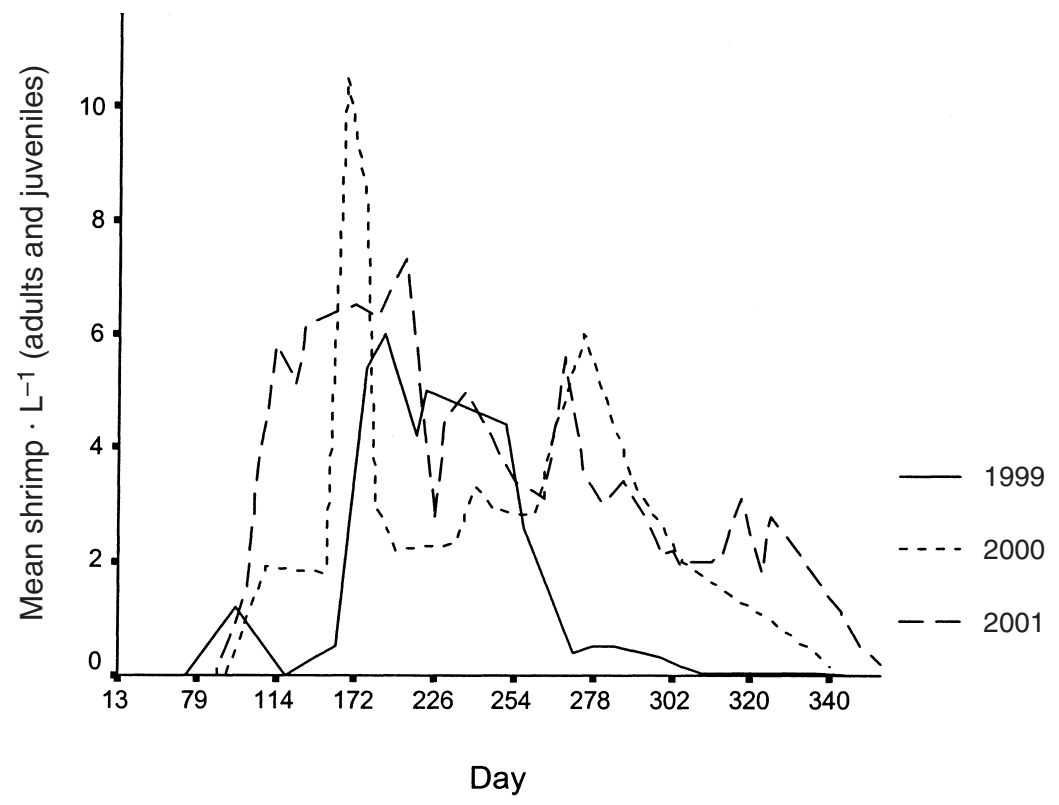

Fig. 1. Average adult and juvenile brine shrimp density from Gilbert Bay, Great Salt Lake, Utah, determined by the Utah Division of Wildlife Resource and the U.S. Geological Survey in 1999, 2000, and 2001. Grebes departed the lake from 16 November through 15 December 1999 and from 23 November through 25 December 2000 (J. Jehl, Jr., Hubbs Sea World Institute, personal communication). In 2001 grebes departed from approximately mid-November through mid- to late December.

\section{Scan Sampling}

We observed 256 groups of birds in 1999 (Figs. 2, 3), 542 groups in 2000 (Figs. 4, 5), and 323 groups of birds in 2001 (Figs. 6, 7) using the scan-sampling method. We found a statistically significant difference among groups for the year and month in 1999 and 2000; however, the effect size was small (Table 1). There was not a statistically significant effect by the hour of day (Table 1). Flock size, which ranged from 1 to 14 , was not correlated with the percentage of time spent in the diving portion of the diving bout $(r=-0.11)$, in the surface portion of the diving bout $(r<0.01)$, or surface swimming $(r=0.05)$. Because these effects did not appear to be significant in 1999 or 2000 , we did not include these tests in our analysis of the 2001 data.

In the fall we observed 115, 252, and 129 groups of grebes in 1999, 2000, and 2001, respectively. Grebes spent an average of 0.90 $(s=0.18)$ daylight hours foraging in 1999, 0.65 $(s=0.30)$ daylight hours foraging in 2000 , and $0.67(s=0.29)$ daylight hours foraging in 2001 . While there was a significant difference between years $(P<0.001)$, the difference in time spent foraging between 2000 and 2001 was not significant $(P=0.76)$. Grebes spent more time foraging in 1999 than in 2000 or $2001(P<0.001)$.

\section{Eared Grebe Mass}

The GLM showed that, overall, adult grebes weighed more in 1999 and 2000 than in 2001 $(P \leq 0.01$, Fig. 8$)$. However, there were no significant differences $(P>0.05)$ between each week of 2001 and the other years except for weeks 37 and 38 (Fig. 9). Subadult grebes weighed less during fall 1999 than in fall 2000 or 2001 (Fig. 8). There were some significant differences $(P \leq 0.05)$ in weight during weeks 41, 43, and 45 (Fig. 10). Juvenile grebes weighed less $(P<0.001)$ in 1999 and 2001 than in 2000 (Fig. 8). During weeks 40, 41, 42, 44, 45, and 46 there were significant differences $(P \leq 0.05)$ in grebe weights (Fig. 11).

\section{Discussion}

One potential bias in our behavioral data is that grebes along the AIC tend to forage in distinct age groups (D.S. Paul, UDWR, personal communication). Because we observed a group of birds for an hour and then drove to a 


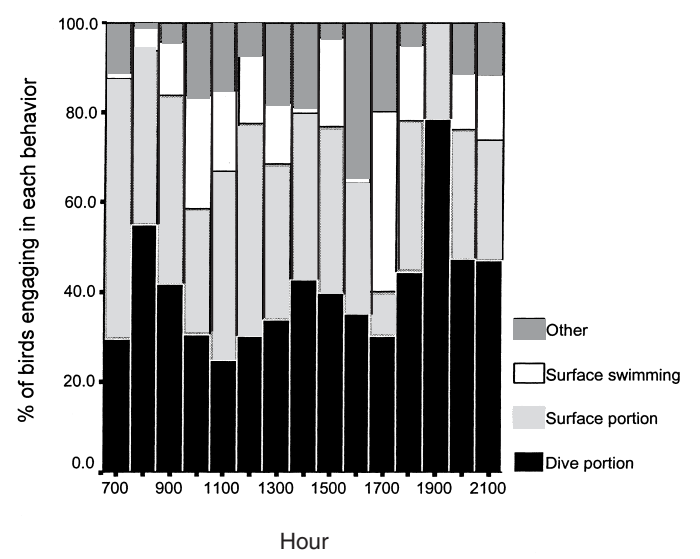

Fig. 2. Summary of behavior from scan sampling of Eared Grebes on the Great Salt Lake, Utah, May-August 1999. Dive portion is the diving portion of a diving bout. Surface portion is the surface portion of a diving bout.

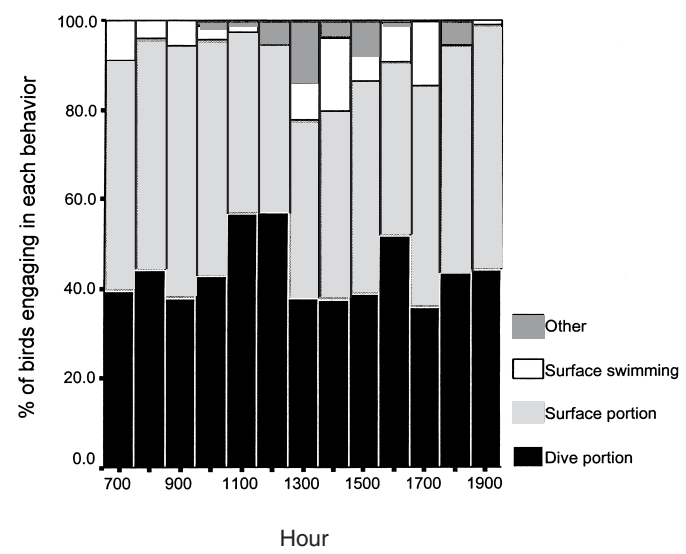

Fig. 3. Summary of behavior from scan sampling of Eared Grebes on the Great Salt Lake, Utah, September-November 1999. Dive portion is the diving portion of a diving bout. Surface portion is the surface portion of a diving bout.

new location at least $100 \mathrm{~m}$ away, we probably did not predominantly sample one age class over another. Adult grebes also tend to stay further away from the AIC than juveniles. Our observations included grebes both near the AIC and $500 \mathrm{~m}$ away from it, and consisted of a relatively large sample of birds throughout the year. Therefore, our time budget should be sufficient in conjunction with an energy budget to determine the average energetic need of Eared Grebes on the GSL.

There is another potential bias that showed up in the grebe mass data in 2001 . We primarily

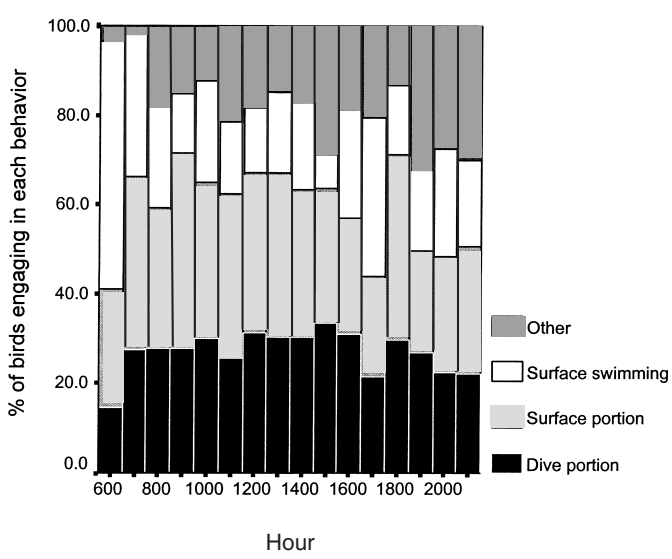

Fig. 4. Summary of behavior from scan sampling of Eared Grebes on the Great Salt Lake, Utah, May-August 2000. Dive portion is the diving portion of a diving bout. Surface portion is the surface portion of a diving bout.

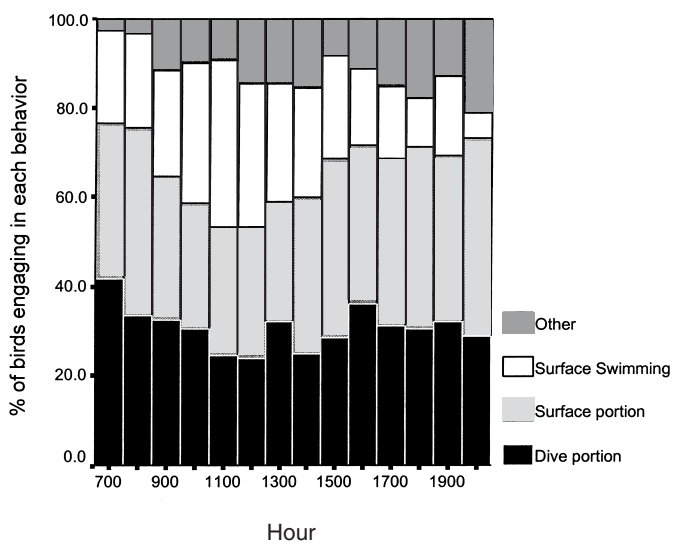

Fig. 5. Summary of behavior from scan sampling of Eared Grebes on the Great Salt Lake, Utah, September-November 2000. Dive portion is the diving portion of a diving bout. Surface portion is the surface portion of a diving bout.

collected grebes between the AIC and Fremont Island, around Antelope Island, and in Farmington Bay. Grebes frequently move around the lake, presumably to take advantage of greater densities of shrimp. Our sampling frequency was less in 2001 than in previous years. During some days there were few grebes in these areas to capture, and those we captured were often underweight. Grebes present in the flocks moving in from other areas of the lake were heavier than the few that stayed in the area the entire time. Because of our reduced sampling effort, these lighter grebes increased 


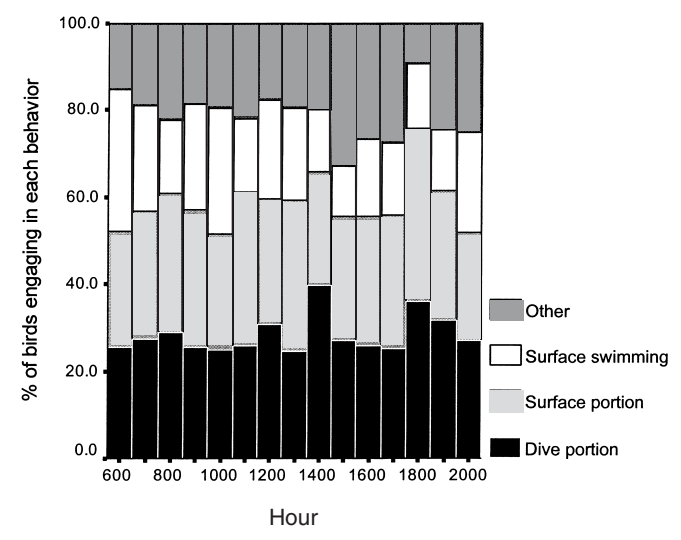

Fig. 6. Summary of behavior from scan sampling of Eared Grebes on the Great Salt Lake, Utah, May-August 2001. Dive portion is the diving portion of a diving bout. Surface portion is the surface portion of a diving bout.

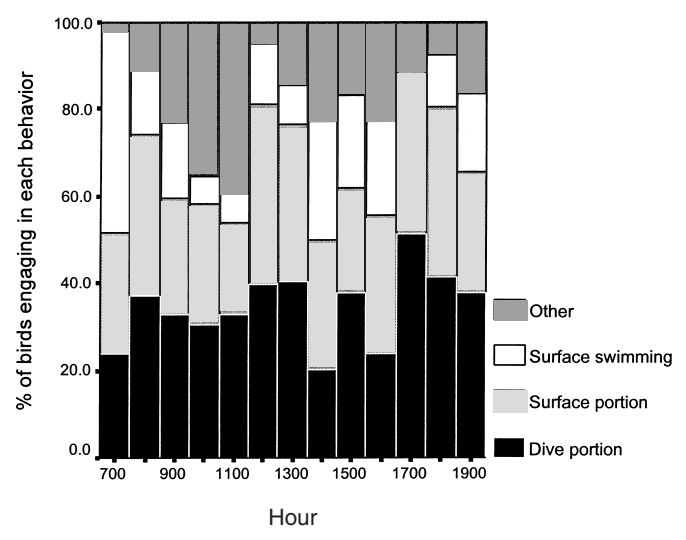

Fig. 7. Summary of behavior from scan sampling of Eared Grebes on the Great Salt Lake, Utah, September- November 2001. Dive portion is the diving portion of a diving bout. Surface portion is the surface portion of a diving bout.

TABLE 1. Comparisons (general linear model) of the percentage of time Eared Grebes spent in each behavior among years, months, and hours on the Great Salt Lake, Utah, in 1999 and 2000. Diving portion is the diving portion of a diving bout. Surface portion is the surface portion of a diving bout.

\begin{tabular}{|c|c|c|c|c|c|c|c|}
\hline Activity & Factor & df & MS & $F$ & $P$ & $\mathrm{Eta}^{2}$ & Power \\
\hline \multirow[t]{3}{*}{ Diving portion } & Year & 1 & 1.68 & 39.52 & $<0.001$ & 0.06 & 1.00 \\
\hline & Month & 6 & 0.19 & 4.76 & $<0.001$ & 0.04 & 0.99 \\
\hline & Hour & 15 & 0.06 & 1.36 & 0.158 & 0.03 & 0.83 \\
\hline \multirow[t]{3}{*}{ Surface portion } & Year & 1 & 0.37 & 7.09 & 0.008 & 0.01 & 0.76 \\
\hline & Month & 6 & 0.17 & 3.29 & 0.003 & 0.03 & 0.94 \\
\hline & Hour & 15 & 0.08 & 1.49 & 0.101 & 0.03 & 0.87 \\
\hline \multirow[t]{3}{*}{ Surface swimming } & Year & 1 & 1.54 & 27.16 & $<0.001$ & 0.04 & 1.00 \\
\hline & Month & 6 & 0.10 & 1.83 & 0.092 & 0.02 & 0.67 \\
\hline & Hour & 15 & 0.08 & 1.38 & 0.153 & 0.03 & 0.84 \\
\hline
\end{tabular}

the standard error of the means and caused the grebes in 2001 to be lighter than those of other years.

Eared Grebes must collect enough shrimp to meet their daily energetic requirements and store enough fat to continue their migration to the Salton Sea. This seems to be a difficult feat considering the mean wet weight of a brine shrimp is only $0.002 \mathrm{~g}$. Upon arriving at the GSL, most Eared Grebes undergo a complete molt of their primaries and begin to increase their body mass. Jehl (1988) reported that Eared Grebes more than double their mass about 2 months after reaching Mono Lake, California, putting on large amounts of fat reserves in the process. During this time the pectoral muscles atrophy below a size necessary for flight, and their stomach and intes- tines increase in size. Prior to departure from Mono Lake, this trend in organ size is reversed; the flight muscles increase in size while digestive organs atrophy. The heart muscle also increases and fat is catabolized. This maximizes flight range and performance and minimizes wing loading (Jehl 1988, Cullen et al. 1999). It is unclear what adaptive advantage these rapid changes in organ size have for the grebes. However, Eared Grebes appear to survive from fat reserves while breast muscles are regenerating prior to migration. If Eared Grebes cannot acquire enough food to put on this additional weight for subsequent conversion to muscle mass, or cannot spend enough time wing flapping to build up their breast muscles, they might not be able to leave the GSL or might not have enough energy to complete 


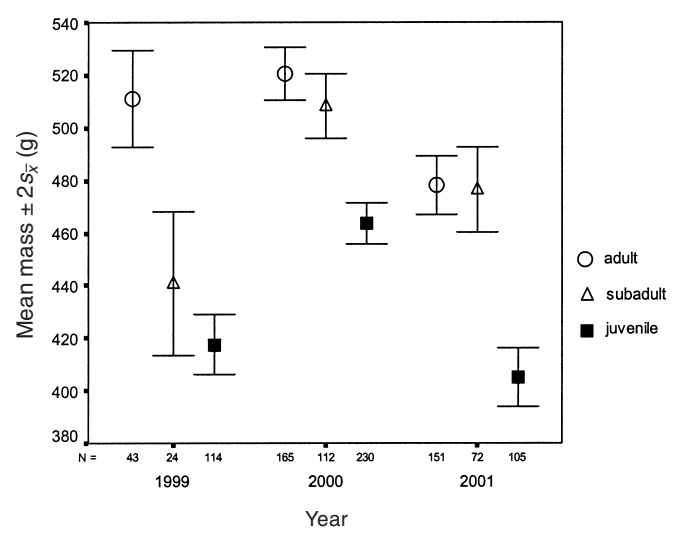

Fig. 8. Seasonal mean mass of adult, subadult, and juvenile Eared Grebes captured between late August and December 1999, 2000, and 2001 on the Great Salt Lake, Utah.

migration. As shrimp populations on the GSL decline during the fall, grebes can respond in several ways. They can (1) increase the duration of a diving bout, (2) decrease the surface duration of a foraging bout, (3) increase the total time spent foraging and decrease the time spent resting or preening, (4) start to fast and decrease all activities except resting and preening, (5) increase swimming to find patches of higher shrimp densities, or (6) migrate.

Grebes could respond to low shrimp densities by increasing the amount of time spent underwater, thereby allowing them greater opportunity to catch more shrimp. We found no difference between years or months indicating that grebes alter the duration of a dive in response to a lower shrimp density. These results concur with Jehl's (1988) observation of dive durations of Eared Grebes on Mono Lake. These results were not unexpected because dive duration did not appear to affect the energy consumption of Eared Grebes in a foraging bout (i.e., grebes expend approximately the same amount of energy in linear dives of 10-40 seconds; Caudell 2001). Therefore, grebes should maximize their dive duration because the energetic cost is not greatly affected by additional time spent underwater up to 40 seconds. Alternatively, grebes could respond to low shrimp densities by decreasing the amount of time between dives (surface duration) during a diving bout. However, there did not appear to be any difference in surface duration between years when shrimp densities were low and years when they were high.
As shrimp populations decline, grebes can spend less time each day preening, resting, and in other activities and more time foraging. During fall 2000 and fall 2001, when shrimp were abundant, grebes spent about $70 \%$ of their time in foraging bouts (diving + surface interval). However, during fall 1999 when shrimp densities were much lower, between 0.5 and 0.1 shrimp $\cdot \mathrm{L}^{-1}$, grebes spent most of their time (mean $>90 \%$ ) in foraging bouts. If shrimp populations decrease further than the densities measured during 1999, grebes would have to spend additional time foraging to meet their daily energetic requirements. However, there is an upper limit to the time that grebes can spend foraging each day because they must spend a certain amount of time preening and resting. Grebes are also limited to foraging during daylight hours (Cooper et al. 1984) because they locate food by sight. Therefore, it would be nearly impossible for grebes to spend additional time foraging in a 24-hour period. If the grebes cannot gather enough shrimp to offset their daily energetic requirements and put on enough fat, then they might not be able to complete their migration.

During July and August shrimp densities were higher during 1999 than during 2000 (Fig. 1). However, grebes did not spend more time foraging (surface and underwater portions of a diving bout) during 2000 than during 1999. While shrimp densities were lower during July and August 2000 when compared to these months during 1999, densities during 2000 did not drop below 2 shrimp $\cdot \mathrm{L}^{-1}$ (Fig. 1). One explanation as to why grebes did not increase foraging effort during these months in 2000 when shrimp density was lower than in 1999 is that extremely low shrimp densities are required, such as those present on the GSL during fall 1999, to trigger greater foraging effort. Also, grebes do not begin putting on additional weight until the fall. Hence, they might not significantly increase foraging effort until then. Grebes on the lake during spring and summer 1999 might also have been food stressed in the spring and increased their foraging efforts in response to a potentially poor year.

Shrimp populations can drop so low that grebes would not be able to catch enough shrimp to offset the energetic output used to forage. In this instance, they could forage less often or less rapidly in order to conserve energy. 


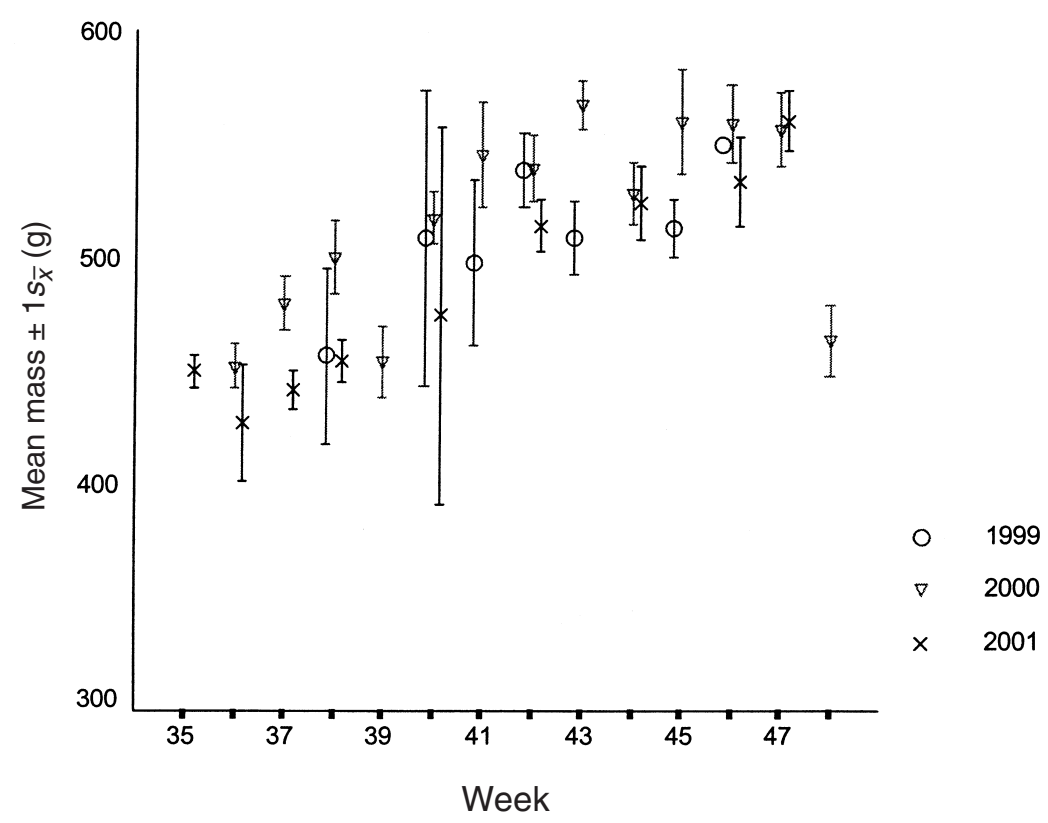

Fig. 9. Mass of adult Eared Grebes captured weekly between late August and December 1999, 2000, and 2001 on the Great Salt Lake, Utah.

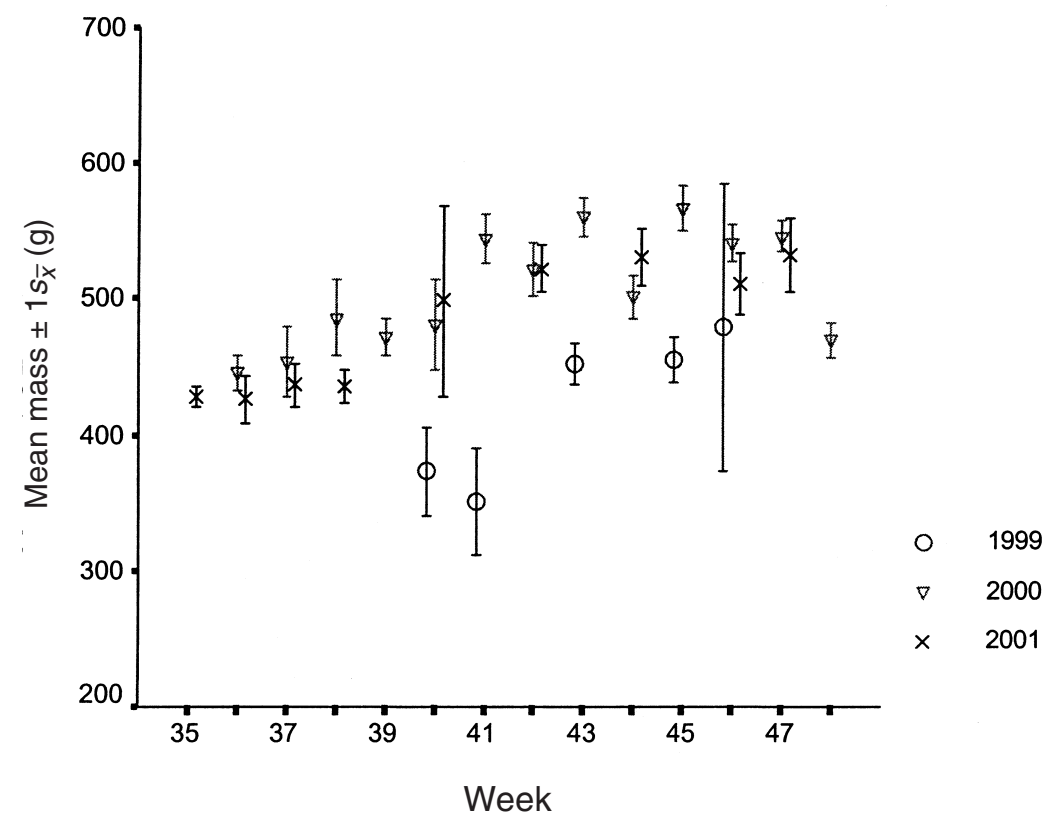

Fig. 10. Mass of subadult Eared Grebes captured weekly between late August and December 1999, 2000, and 2001 on the Great Salt Lake, Utah. 


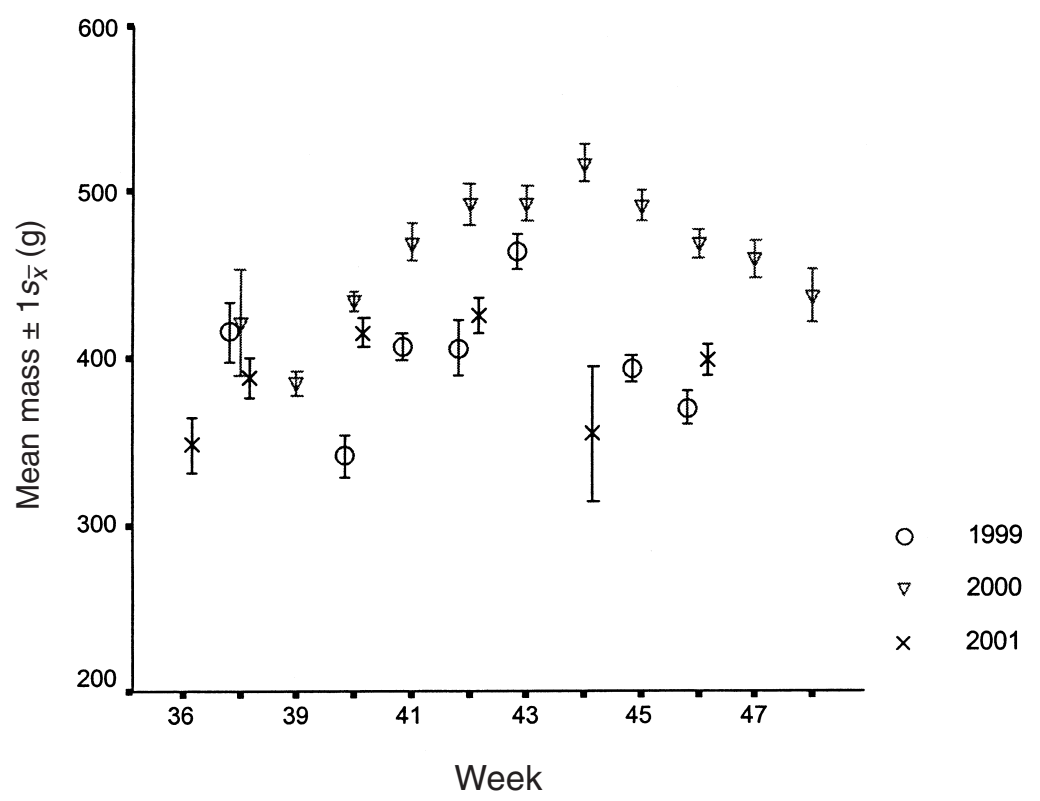

Fig. 11. Mass of juvenile Eared Grebes captured weekly between late August and December 1999, 2000, and 2001 on the Great Salt Lake, Utah.

Jehl (1988) reported this behavior on Mono Lake when shrimp populations begin to die off in the winter. However, this response was not seen in grebes on the GSL during our study. One possible explanation is that the shrimp population never reached this critical density prior to grebe migration. This minimum density on the GSL would have to be determined by observing grebes foraging at even lower shrimp densities than those reported in 1999 or by modeling the response of grebes to various shrimp densities.

Grebes may respond to declining food resources by foraging in patches that have more abundant shrimp. This should result in more frequent surface swimming between diving bouts to reach these patches of higher shrimp density. However, in fall 1999 when food was most scarce (Table 1), grebes spent less time swimming and more time in diving bouts. Hence grebes did not respond to declining shrimp densities by spending more time searching for patches with high densities of shrimp. While the brine shrimp population on the GSL is not homogenous (M. Hunwick, UDWR, personal communication), shrimp patches of higher density may not be different enough to trigger movement in Eared Grebes or the grebes are unable to detect them.
Jehl (1988) hypothesized that grebes would leave Mono Lake once brine shrimp decrease below a critical density of 3000 shrimp $\cdot \mathrm{m}^{-2}$. We converted this value to shrimp $\cdot \mathrm{L}^{-1}$ based on his measurements using a 0.3-m-diameter net and using an average depth of $17 \mathrm{~m}$ (Jehl 1988) in Mono Lake, resulting in a density of approximately 0.5 shrimp $\cdot \mathrm{L}^{-1}$. Hence, during 1999 grebes should have left the GSL earlier in the year than they did during 2000 or 2001 when shrimp densities were higher. However, this did not occur during our study. Grebes remained on the GSL until late November and early December and left about the same time all 3 years (Fig. 1). Based on our results, it appears that grebes increase their foraging effort in response to declining food resources at shrimp densities between 0.1 and 0.5 shrimp - $\mathrm{L}^{-1}$. Therefore, if there is a critical shrimp density where the grebes cease foraging, it may be below 0.1 shrimp $\cdot \mathrm{L}^{-1}$, but we cannot ascertain the critical density level based on our observations.

Grebes responded to low shrimp densities in 1999 by increasing overall time spent foraging. However, it appears that they may be near an upper limit for the amount of time they can spend foraging each day. If shrimp densities decrease further, they may be forced to spend 
additional time underwater, conserve energy, migrate, or use one of the other strategies we discussed. Results of weight measurements indicate that low shrimp density in 1999 affected the adults very little, and only moderately affected juveniles and subadults. To determine the shrimp density that would negatively affect grebes will require additional monitoring of grebe behavior in years of poor shrimp production or modeling the potential responses of grebes at different shrimp densities.

\section{ACKNOWLEDGMENTS}

We thank J. Butler-Curl and J. Curl for their assistance in capturing Eared Grebes and conducting other fieldwork on our project and G. Taylor and Antelope Island State Park for the use of the marina and park for our metabolic rate experiments, observational studies, and monitoring of grebe weights. Members of the GSL Ecosystem Project Technical Advisory Group were especially helpful during the course of this project, particularly G. Belovsky, P. Birdsey, and C. Perschon. We thank A. Brown, N. Frey, H. Ellis, and J. Jehl, Jr., for commenting on this manuscript. J. Jehl, Jr., also provided information on the departure dates of Eared Grebes from the GSL. Funding for this project was provided by the UDWR through the GSL Ecosystem Project and by the Jack H. Berryman Institute for Wildlife Damage Management at Utah State University.

\section{Literature Cited}

Adair, S.E., J.L. Moore, and W.H. Kiel, JR. 1996. Wintering diving duck use of coastal ponds: an analysis of alternative hypothesis. Journal of Wildlife Management 60:83-93.

Altmann, J. 1974. Observational study of behavior: sampling methods. Behaviour 49:227-265.

ButTS, D.S. 1980. Factors affecting the concentrations of Great Salt Lake brines. Pages 163-167 in J.W. Gwynn, editor, Great Salt Lake: a scientific, historical, and economic overview. Utah Department of Natural Resources, Salt Lake City.

Caudell, J.N. 2001. Biology of Eared Grebes (Podiceps nigricollis) on the Great Salt Lake, Utah. Doctoral dissertation, Utah State University, Logan.

Cooper, S.D., D.W. Winkler, And P.H. Lenz. 1984. The effect of grebe predation on a brine shrimp population. Journal of Animal Ecology 53:51-64.

Cullen, S.A., J.R. Jehl, Jr., and G.L. Nuechterlein. 1999. Eared Grebes (Podiceps nigricollis). Pages 1-28 in A. Poole and F. Gill, editors, The birds of North America, no. 433. The Birds of North America, Inc., Philadelphia, PA.

Gates, R.J., D.F. Caithamer, W.E. Moritz, and T.C. TACHA. 2001. Bioenergetics and nutrition of Mississippi Valley population Canada Geese during winter and migration. Wildlife Monographs 146:1-65.

Gliwicz, Z.M., W.A. Wurtsbaugh, and A. Ward. 1995. June 1994-May 1995 performance report to the Utah Division of Wildlife Resources, Salt Lake City, Utah. Utah Division of Wildlife Resources, Salt Lake City.

Hulbert, S.H. 1984. Pseudoreplication and the design of ecological field experiments. Ecological Monographs 54:187-211.

JEHL, J.R., JR. 1985. Leucism in Eared Grebes in western North America. Condor 87:439-441.

1988. Biology of the Eared Grebe and Wilson's phalarope in the nonbreeding season: a study of adaptations to saline lakes. Studies in Avian Biology No. 12. Cooper Ornithological Society, University of California, Los Angeles, CA.

Jehl, J.R., JR., A.E. Henry, And S.I. Bond. 1998. Sexing Eared Grebes by bill measurements. Colonial Waterbirds 21:98-100.

O’Donnel, C., AND J. FJeldSA. 1997. Grebes: status survey and conservation action plan. International Union for Conservation of Nature and Natural Resources, Cambridge, U.K.

Paul, D.S., E.M. Annand, And J. Flory. 1999a. Great Salt Lake waterbird survey: 1997 and 1998 seasons. Number 99-19, Utah Division of Wildlife Resources, Salt Lake City.

Paul, D.S., J. Flory, And E.M. AnNand. 1999b. 1997 Great Salt Lake Eared Grebe photo survey. Number 99-20, Utah Division of Wildlife Resources, Salt Lake City.

RawLEY, E.V. 1980. Wildlife of the Great Salt Lake. Pages 287-304 in J.W. Gwynn, editor, Great Salt Lake: a scientific, historical, and economic overview. Utah Department of Natural Resources, Salt Lake City.

Statistical Package for the Social Sciences. 2000. Version 10. SPSS, Inc., Chicago, IL.

Stephens, D.W. 1999. Brine shrimp ecology in the Great Salt Lake, Utah: July 1997 through June 1998. Utah Geological Survey, Salt Lake City.

. 2000. Brine shrimp ecology in the Great Salt Lake, Utah: July 1998 through June 1999. Utah Geological Survey, Salt Lake City.

Stevens, J. 1999. Intermediate statistics: a modern approach. 2nd edition. Lawrence Erlbaum Associates, Mahwah, NJ.

Storer, R.W., AND J.R. JehL, JR. 1985. Moult patterns and moult migration in the Black-necked Grebe Podiceps nigricollis. Ornis Scandinavica 16:253-260.

WAKELEY, J.S. 1978. Activity budgets, energy expenditure, and energy intake of nesting Ferruginous Hawks. Auk 95:667-676.

Received 20 July 2004 Accepted 5 April 2005 